\title{
Cartel criminalisation and due process: the challenge of imposing criminal sanctions alongside administrative sanctions within the EU
}

\author{
Dr Peter Whelan*
}

University of East Anglia

\begin{abstract}
$\underline{\text { Abstract }}$
There is increasing debate within the European Union (EU) concerning the imposition of criminal sanctions upon those individuals who engage in cartel activity. For it to be legitimate, such cartel criminalisation must respect the due process guarantees contained in the European Convention on Human Rights (ECHR). Unfortunately the literature on this issue is deficient and the specifics of this legal challenge are not fully understood. In particular, a comprehensive analysis of the due process-related challenge presented when personal criminal antitrust sanctions are employed alongside administrative sanctions for a given cartel is conspicuously absent from the literature. This article rectifies this deficiency by examining this particular legal challenge and its relevance to information exchange, double jeopardy and concurrent antitrust proceedings. In doing so, it identifies practical techniques designed to meet the challenge of due process in this context, as well as the inherent tensions between due process and the objectives of European antitrust criminalisation.
\end{abstract}

Keywords: anti-cartel enforcement; concurrent proceedings; criminal cartel sanctions; due process; EU competition law; information exchange; ne bis in idem.

\section{Introduction}

6 Cartel activity' encapsulates the making or implementing of an anticompetitive agreement, concerted practice or arrangement by competitors to fix prices, rig bids, establish output restrictions or divide markets. ${ }^{1}$ Such activity is prohibited by all of the national competition laws of the EU member states. Furthermore, if it affects trade between the member states, cartel activity is prohibited by art 101(1) of the Treaty on the Functioning of the European Union (TFEU), which is enforced by the European Commission (the Commission) and the national competition authorities (NCAs) and courts of the member states. ${ }^{2}$ Traditionally, within Europe, cartel law enforcement has tended to

* $\quad \mathrm{PhD}$ (Cantab), Senior Lecturer in Law, UEA Law School and ESRC Centre for Competition Policy, University of East Anglia; email: p.whelan@uea.ac.uk.

1 OECD, Recommendation of the OECD Council Concerning Effective Action Against Hard Core Cartels, 25 March 1998, $[2(a)]$.

2 See Council of Ministers, Council Regulation (EC) No 1/2003 of 16 December 2002 on the implementation of the rules on competition laid down in arts 81 and 82 of the Treaty, [2003] OJ L1/1 (hereafter 'reg 1/2003'). 
avoid the employment of personal criminal punishment. ${ }^{3}$ Recently, however, there has been increasing debate concerning the imprisonment of individual cartelists. ${ }^{4}$ This debate is more than an academic exercise: some European countries have criminalised their antitrust regimes, while others have contemplated doing so.

Cartel criminalisation within the EU presents complex challenges. Advocates of criminalisation must demonstrate, for example, that it is justifiable in principle. This is often accomplished using (economic) deterrence or retribution theory; deterrence and retribution therefore represent the primary enforcement objectives of European antitrust criminalisation. ${ }^{5}$ Additionally, advocates must demonstrate that such criminalisation can adhere to relevant mandatory legalities. In particular, to attain legitimacy, antitrust criminalisation should respect the due process guarantees contained in the ECHR. It is vital therefore to understand how due process impacts upon the mechanics of antitrust criminalisation and whether practical measures and techniques are required to respect due process. Importantly, one must also understand whether respecting due process impacts negatively upon the two primary objectives of European antitrust criminalisation. Indeed, the existence of such an impact should influence the initial decision whether to criminalise. Failure to respect due process in this context may lead to the creation of a criminal antitrust regime which is not only legally unsound, but which also wastes resources and creates negative publicity for the antitrust regime.

Admittedly, one aspect of due process has been considered in the literature: the claim that antitrust criminalisation inevitably results in a 'strengthening of rights' to the benefit of the accused and to the detriment of the relevant enforcement objectives. ${ }^{6}$ In examining the 'strengthening of rights' contention, one analyses whether imposing criminal sanctions rather than administrative sanctions for a given cartel engenders potential negative implications for antitrust enforcement due to human rights considerations. However, to present a complete picture of the challenge of due process for European antitrust criminalisation, one must go further and consider the potential interaction of both criminal and administrative cartel sanctions in this context. Specifically, one should first explore whether the introduction of criminal antitrust sanctions does not preclude the imposition of administrative sanctions alongside such criminal sanctions for a given cartel (herein termed the 'additional dynamic' contention), before examining the impact of that particular contention upon criminal antitrust enforcement that respects due process.

The current (fragmented) literature alludes somewhat to the additional dynamic contention and its potential impact. Perrin, for example, argues that, due to concerns for human rights, the fact that criminal antitrust sanctions exist in some EU member states but not in others (where only administrative sanctions exist) impacts negatively on European cooperation in antitrust enforcement. ${ }^{7}$ Zuleeg questions whether the mere existence of both criminal and administrative antitrust procedures within Europe has the potential to

3 See C Harding, 'Business Collusion as a Criminological Phenomenon: Exploring the Global Criminalisation of Business Cartels’ (2006) 14 Critical Criminology 181.

4 See generally C Beaton-Wells and A Ezrachi (eds), Criminalising Cartels: Critical Studies of an International Regulatory Movement (Hart Publishing 2011).

5 See P Whelan, The Criminalization of European Cartel Enforcement: Theoretical, Legal, and Practical Challenges (OUP forthcoming).

6 P Whelan, 'Criminal Cartel Enforcement in the European Union: Avoiding a Human Rights Trade-Off' in Beaton-Wells and Ezrachi (n 4).

7 B Perrin, 'Challenges Facing the EU Network of Competition Authorities: Insights from a Comparative Criminal Law Perspective’ (2006) 31(4) European Law Review 540. 
violate the accused's right not to be punished twice for the same conduct. ${ }^{8}$ Finally, Nazzini considers whether the existence of the UK Cartel Offence introduces human rights-based problems due to the possibility of concurrent criminal and administrative proceedings. ${ }^{9}$ Notwithstanding this literature, to date, no systematic analysis has been undertaken concerning the validity and impact of the additional dynamic contention upon European cartel criminalisation. This situation is regrettable.

This article examines the validity of the additional dynamic contention, as well as its impact upon a project of European antitrust criminalisation which respects due process. It is divided into two substantive sections. Section 1 determines the validity of the additional dynamic contention by considering the likelihood and legality of four of its potential manifestations. By contrast, section 2 examines the impact of the additional dynamic contention: it examines the specifics of the due process-related challenge presented when personal criminal antitrust sanctions are indeed employed alongside administrative sanctions. Three issues are considered: information exchange; double jeopardy; and concurrent proceedings. Practical techniques designed to meet the challenge of respecting due process are identified, as are the inherent tensions between due process and the objectives of European antitrust criminalisation, before concluding observations are offered.

\section{Determining the validity of the additional dynamic contention}

The additional dynamic contention posits that the introduction of criminal antitrust sanctions in a particular jurisdiction does not preclude the imposition of administrative sanctions alongside such criminal sanctions for a given cartel. There are four potential manifestations of this contention within the EU: (a) a national regime imposes both administrative sanctions on undertakings and criminal sanctions on individuals; (b) a national regime imposes criminal sanctions on individuals and a different national regime imposes administrative sanctions on undertakings; (c) the Commission imposes administrative sanctions on undertakings and a national regime imposes criminal sanctions on individuals; and (d) the Commission imposes criminal sanctions on individuals and a national regime imposes administrative sanctions on undertakings. To examine the validity of the additional dynamic contention, one must therefore examine the legality and likelihood of manifestations (a) to (d).

\section{(A) INQUIRIES RELEVANT TO THE DETERMINATION OF VALIDITY}

Three inquiries should be undertaken to examine the legality and likelihood of the identified manifestations of the additional dynamic contention: (i) whether EU law allows a national regime to adopt both criminal and administrative sanctions; (ii) whether the EU can mandate the adoption of (and/or impose) criminal antitrust sanctions; and (iii) whether diversity concerning antitrust sanctions actually exists across the member states.

\section{(i) National competences concerning antitrust sanctions}

EU law does not prevent member states from choosing whether to impose criminal and/or administrative sanctions for violation of art 101 TFEU. This is clear from reg $1 / 2003$. Recital 16 of that particular regulation, for example, acknowledges the possibility of diversity in enforcement when it provides that 'as regards natural persons, they may be

8 M Zuleeg, 'Criminal Sanctions to be Imposed on Individuals as Enforcement Instruments in European Competition Law' in C D Ehlermann and I Atanasiu (eds), European Competition Law Annual 2001: Effective Private Enforcement of EC Antitrust Law (Hart Publishing 2002) 13.

9 R Nazzini, 'Criminalisation of Cartels and Concurrent Proceedings' (2003) 24(10) European Competition Law Review 483. 
subject to substantially different types of sanctions across the various systems'. Furthermore, art 5 of the same regulation explicitly grants the member states the right to decide on the nature of the antitrust sanction to be imposed for violation of art 101 TFEU: the NCAs may take decisions 'imposing fines, periodic penalty payments or any other penalty provided for in their national law'. ${ }^{10}$ It is clear from art 12(3) of reg 1/2003 that the 'other penalty' referred to includes individual criminal sanctions. ${ }^{11}$ The essence of art 12(3) is that the NCAs may exchange information for the purpose of enforcing art 101 TFEU, but such information may only be used in evidence to impose custodial sanctions on individuals when both the sending and the receiving member states impose 'sanctions of a similar kind'. Nothing in the regulation or in EU jurisprudence prevents the use of both administrative and criminal sanctions by national regimes for a given cartel. Regulation 1/2003 reflects the traditional deference of the European institutions to national procedural autonomy. Consequently, and subject to general principles of EU law, such as equivalence and effectiveness, the member states have the freedom to choose their type of antitrust sanctions. Under EU law at least, both criminal and administrative sanctions remain possible sanctions for cartel activity.

Even if EU law does not prohibit different types of antitrust sanctions, it does not necessarily follow that national law will be so flexible. In some countries particular types of sanctions may be prohibited by national constitutions. In Ireland, for example, sanctions imposed for violation of art 101 TFEU cannot be administrative sanctions: due to arts 34(1) and 37(1) of the Irish Constitution, antitrust sanctions can only be imposed by courts composed of judges appointed in accordance with the Irish Constitution. ${ }^{12}$ This situation is not the norm across Europe, however. National regimes usually have the choice between criminal and administrative antitrust sanctions. Accordingly, subject to the (Irish-inspired) caveat above, ' $\mathrm{t}]$ he national systems to enforce European competition rules can be designed as a criminal law system, an administrative law system or both'.13

\section{(ii) EU competence concerning criminal antitrust sanctions}

In 2005 Wils argued that, under the (now defunct) European Community (EC) treaty framework, the European institutions could both mandate the introduction of criminal antitrust sanctions in the member states and impose such sanctions on individuals at the level of the (then) EC institutions. ${ }^{14}$ He argued: (a) that criminal EC antitrust sanctions were not expressly probibited by EU law; (b) that the Commission had broad legislative enforcement powers under art 83 of the Treaty establishing the European Community (TEC) to adopt 'the appropriate regulations or directives to give effect to the principles set out in [art] 81 [TEC]', principles that underlined the undesirability of hard-core cartels; and (c) that art 81 TEC's use of the term 'undertaking' did not preclude individual (criminal) sanctions, as the measures adopted under art 83 TEC gave effect to the principles inherent in art 81 TEC. Wils acknowledged, however, that his argument would be undermined if the EU Constitution entered into force: the argument relied upon (then) art 47 of the Treaty on European Union (TEU) and the fact that the EU Treaty provisions on criminal matters had no impact upon the TEC antitrust provisions; the EU Constitution would have integrated the areas covered

10 Emphasis added.

11 See W Wils, 'Is Criminalization of EU Competition Law the Answer?’ (2005) 28(2) World Competition 17.

12 See P Massey, 'Criminal Sanctions for Competition Law: A Review of Irish Experience' (2004) 1(1) Competition Law Review 23, 24.

13 O Jansen, 'The Systems of International Cooperation in Administrative and Criminal Matters in Relation to Regulation EC 1/2003' in G Dannecker and O Jansen (eds), Competition Law Sanctioning in the European Union (Kluwer Law International 2004) 258.

14 Wils (n 11). 
by the TEC and by the other Titles of the EU Treaty into 'a single Treaty, without any hierarchy of the former over the latter', ensuring that the antitrust provisions would no longer be treated separately from (limited) EU powers over criminal matters. ${ }^{15}$

An identical effect occurred with the adoption of the Lisbon Treaty. ${ }^{16}$ Although the Lisbon Treaty actually consists of two founding treaties, it abolished any hierarchy between the amended TEU and the TEC (renamed the TFEU). Indeed, the Lisbon Treaty established one single union legal order founded on two treaties with the same value. ${ }^{17}$ Consequently, the antitrust provisions must be interpreted in light of those provisions concerning judicial cooperation on criminal matters. Union legislative competence in the criminal sphere is now provided for in the context of judicial cooperation on criminal matters. ${ }^{18}$ Consequently, one cannot argue that art 103 TFEU (the provision in the TFEU that is equivalent to art 83 TEC) can be used to legislate for criminal sanctions. Regarding the TFEU provisions on judicial cooperation on criminal matters, it is stipulated that in a certain number of enumerated areas directives may be adopted establishing minimum rules concerning the definition of criminal offences and sanctions. Cartel activity is not mentioned but may be included by virtue of art 83(1), para 3, TFEU. For this to happen, the European Council must unanimously adopt a decision after obtaining the consent of the European Parliament. Legislative competence in criminal matters is restricted to the use of directives and therefore would not cover the criminalisation of cartel activity at the level of the EU institutions. So antitrust criminalisation via the EU institutions is facilitated by the Lisbon Treaty, but it is confined to harmonisation of the enforcement regimes of the member states and is possible only if a consensus for such sanctions exists among the member states.

\section{(iii) Diversity of antitrust sanctions across the EU}

Currently there exists 'a wide variation in the nature and the level of the penalties' which can be imposed by the Commission and by the NCAs. ${ }^{19}$ While criminal antitrust sanctions are present in some member states (such as Ireland, the UK, Estonia and Germany, for example,), they are noticeably absent in many others (including, for example, Spain, Sweden, Luxembourg and Holland), where administrative sanctions are the norm. ${ }^{20}$ Furthermore, within the criminalised jurisdictions one often finds non-criminal antitrust sanctions which are aimed at undertakings. Such is the case with the UK and Germany, for example. Thus, there is indeed a diversified range of antitrust sanctions, both across the EU and within (some of) the member states.

This diversity is likely to continue. First, for efficiency reasons, criminal antitrust sanctions are unlikely to replace (as opposed to complement) administrative sanctions within a given regime. ${ }^{21}$ Second, not all of the legislative bodies of the member states may be convinced of the merits of European antitrust criminalisation. Such criminalisation presents complex theoretical, legal and practical challenges which may be perceived by a given jurisdiction to be too demanding to be taken on at present. Third, different antitrust

15 Wils (n 11) 158.

16 See P Whelan, 'Contemplating the Future: Personal Criminal Sanctions for Infringement of EC Competition Law' (2008) 19(2) King's Law Journal 364.

17 See arts 1(3) and 1(2) TFEU.

18 See arts 82-86 TFEU.

19 W Wils, 'Community Report' in D Cahill and J D Cooke (eds) (2004), The Modernisation of EU Competition Law Enforcement: FIDE 2004 National Reports (CUP 2004) [190].

20 See Perrin (n 7) 552-54; and M O'Kane, The Law of Criminal Cartels: Practice and Procedure (OUP 2009) 325-27.

21 See eg OFT, An Assessment of Discretionary Penalties Regimes (OFT 1132, October 2009) [1.4]. 
authorities will have different priorities. While some member states have a mature antitrust regime and are better placed to consider criminalisation, others have only been enforcing competition provisions for a short period of time. The latter jurisdictions may (wisely) wish to develop a 'competition culture' before experimenting with criminal sanctions. ${ }^{22}$ Indeed, a strong competition culture and a political commitment to antitrust law are essential for effective criminal antitrust enforcement. Fourth, diversity should continue to exist not only across the EU but also within a given member state. For reasons of deterrence, criminalised jurisdictions should continue to impose administrative cartel sanctions on undertakings: by maintaining the administrative offences, they ensure that firms would not be incentivised to encourage cartel activity among their employees. ${ }^{23}$ Finally, some countries may have more pronounced institutional challenges concerning antitrust criminalisation than others. Sweden, for example, would have to confront its legal prohibition on prosecutorial discretion to ensure that criminal antitrust sanctions do not undermine administrative leniency programmes. ${ }^{24}$ Such institutional differences reduce the attractiveness of criminal sanctions for some jurisdictions. Provided that other member states remain committed to antitrust criminalisation, this fact alone ensures continued diversity across the EU.

\section{(в) Application Of Findings to the 'FOUR MANifestations'}

According to the above findings, only one out of the four manifestations is invalid. The invalid manifestation is the following: the Commission imposes criminal antitrust sanctions on individuals and a national regime imposes administrative antitrust sanctions on undertakings. It is clear from the analysis concerning EU criminal competence that the European institutions cannot actually impose criminal antitrust sanctions, even if, provided strict conditions are fulfilled, they may mandate their adoption within the member states. The three remaining manifestations are valid, however.

The first manifestation (that is, where a given national regime imposes both administrative and criminal sanctions) occurs within the UK, for example, and is not prohibited under EU law. National law may prohibit administrative sanctions, but this will not be the case in every member state. The second manifestation (that is, where a national regime imposes criminal antitrust sanctions on individuals and a different national regime imposes administrative sanctions on undertakings) is facilitated by art 5 of reg 1/2003 and is likely given the different priorities facing different member states and the current absence of a European consensus about the desirability of antitrust criminalisation. The third manifestation (that is, where the Commission imposes administrative antitrust sanctions on undertakings and a national regime imposes individual criminal sanctions) is also valid. This is due, again, to art 5 of $\operatorname{reg} 1 / 2003$, as well as to the fact that the Commission cannot be given the power to impose criminal sanctions. Hence, given that three out of its four manifestations are both legal and likely, the additional dynamic contention itself is valid.

\section{Determining the impact of the additional dynamic contention}

This section acknowledges the validity of the additional dynamic contention and examines its actual impact upon European antitrust criminalisation. Three important issues are considered: (a) information exchange; (b) double jeopardy; and (c) concurrent proceedings.

22 See J Fingleton, M B Girard and S Williams, 'The Fight Against Cartels: Is a "Mixed" Approach to Enforcement the Answer?' in B Hawke (ed), International Antitrust Law and Policy: Fordham Corporate Law 2006 (Juris Publishing 2007) 22.

23 See P Whelan, 'A Principled Argument for Personal Criminal Sanctions as Punishment under EC Cartel Law' (2007) 4(1) Competition Law Review 7, 30-31.

24 See Swedish Competition Authority, 'Criminal Enforcement of Antitrust Laws' (Fordham Law Seminar, New York, 14 September 2006). 


\section{(A) EXCHANGE OF INFORMATION}

The effectiveness of an antitrust investigation often depends upon the extent of cooperation with and assistance received from foreign states. ${ }^{25}$ This is particularly so for cartels: they often cross the boundaries of jurisdictions and 'an agency may not be aware of a cartel affecting its jurisdiction, while another agency has cognisance of it'. ${ }^{26}$ As cartels become increasingly international in nature, cooperation in cartel cases will continue to grow in importance. ${ }^{27}$ Cooperation may take many forms, such as the exchange of information and the collection of evidence. There is consensus on the importance of cooperation in the form of information exchange. ${ }^{28}$ Information exchange helps, inter alia, to increase rates of detection and has a positive impact upon the enforcement objectives of antitrust law. Such cooperation is therefore valuable and should be facilitated where appropriate.

A due process problem may arise with information exchange (within the second and third manifestations of the additional dynamic contention) when the following conditions are fulfilled: (a) personal criminal sanctions are imposed in one jurisdiction for cartel activity, and administrative sanctions are imposed in another; (b) both jurisdictions are investigating a given cartel; and (c) the criminal jurisdiction requests from the other jurisdiction information that has been collected during its respective investigation. If information collected during the administrative investigation could legally be provided to the other jurisdiction (and that jurisdiction could use it in evidence in a criminal trial), potential would exist for a violation of due process: the collection of evidence in the requested state will presumably have been conducted according to administrative standards and not criminal standards. This potential problem should be neutralised for European antitrust criminalisation to be legally sound.

\section{(i) Regulation 1/2003 and the European Competition Network}

Due to reg 1/2003, the Commission and the NCAs cooperate with one another through the European Competition Network $(\mathrm{ECN}){ }^{29}$ This network is an official forum for discussion and cooperation in the application and enforcement of EU competition policy. ${ }^{30}$ For the purpose of applying arts 101 and 102 TFEU, the Commission and the NCAs have the power to provide one another with and use in evidence any matter of fact or of law, including confidential information. ${ }^{31}$ Such cooperation, while legal, is not mandatory. There is a narrow exception to the rule that the information exchanged should only be used in evidence for the purpose of applying arts 101 and 102 TFEU and in respect of the subjectmatter for which it was collected by the transmitting authority: ${ }^{32}$ information exchanged under art 12 may also be used for the application of national competition law, but only where that law 'is applied in the same case and in parallel to Community competition law

25 Perrin (n 7) 540.

26 ICN, 'Co-operation between Competition Agencies in Cartel Investigations' (Report to the ICN Annual Conference, Moscow, 7 May 2007).

$27 \mathrm{ICN}$ (n 26) 5.

28 See M Bloom, 'Exchange of Confidential Information among Members of the EU Network of Competition Authorities' in C D Ehlermann and I Atanasiu (eds), European Competition Law Annual 2002 (Hart Publishing 2004) 389.

29 See reg 1/2001, recital 15 and ch IV (in particular arts 11 and 12).

30 See European Commission, Commission Notice on Cooperation within the Network of Competition Authorities, 2004/C 101/03, Brussels, 24 April 2004 [1].

$31 \operatorname{Reg} 1 / 2003$, art 12(1). See also arts 11(4) and 22(1).

32 See reg 1/2003, art 12(2); and Dow Benelux v Commission (85/87) [1989] ECR 3137. 
and does not lead to a different outcome'. ${ }^{33}$ This power cannot be undermined by national law. ${ }^{34}$ Pursuant to this power, the exchange of information can be either vertical (for instance, from the Commission to the NCAs) or horizontal (that is, between the NCAs). ${ }^{35}$ Consequently, the power to provide information facilitates three types of information flows: from an administrative regime to a criminal regime; from an administrative regime to another administrative regime; and from a criminal regime to an administrative regime.

\section{(ii) Neutralising potential problems of due process with criminalisation within the ECN}

For present purposes, it is the first information flow that is potentially problematic. If during an administrative investigation the Commission discovered evidence of an individual's participation in a cartel involving harm to UK consumers, for example, and was allowed to pass that information on to the UK authorities for them to use as evidence in a criminal court against that individual, the collection of (some of the) evidence would be conducted according to administrative standards and not criminal standards. Administrative protections may be less robust than those required in a criminal context and are in fact so with the Commission's investigations. ${ }^{36}$ Therefore if the power to use exchanged information in this context were unlimited, due process would be undermined. ${ }^{37}$ To avoid this, reg $1 / 2003$ contains art 12(3).

\section{Article $12(3)$ of reg $1 / 2003$}

Article 12(3) of reg 1/2003 states that information exchanged via the ECN can only be used in evidence to impose sanctions upon individuals where:

- the law of the transmitting authority foresees sanctions of a similar kind in relation to an infringement of art 101 TFEU or art 102 TFEU or, in the absence thereof,

- the information has been collected in a way which respects the same level of protection of the rights of defence of natural persons as provided for under the national rules of the receiving authority. However, in this case, the information exchanged cannot be used by the receiving authority to impose custodial sanctions.

Accordingly, reg 1/2003 accommodates antitrust criminalisation in the member states. Those member states which have 'sanctions of a similar kind'38 (for example, custodial sanctions) are allowed to exchange amongst themselves and, importantly, use in evidence against individuals the information that they have collected. The presumption here is that, if personal criminal sanctions are imposed in one country, then due to, inter alia, art 6 ECHR, that country must conduct its investigations in a manner which respects human rights. Indeed, if both jurisdictions have custodial sanctions for cartel activity then the 'procedural safeguards in both systems are considered to be equivalent'. ${ }^{39}$ While a 'common' minimum level of protection may well exist, it is also true that some human

33 Reg 1/2003, art 12(1). If member states wish to exchange information where these conditions are not met, they may require additional legislative provisions: Jansen (n 13) 259.

34 See European Commission (n 30) [27].

35 Jansen (n 13) 258; and European Commission (n 30) [27].

36 See Whelan (n 6).

37 See W Wils, Efficiency and Justice in European Antitrust Enforcement (Hart Publishing 2008) 194; and W Wils, Principles of European Antitrust Enforcement (Hart Publishing 2005) s 1.2.12.

38 It appears that the fundamental criterion that should be used to determine if the personal sanctions are of a 'similar kind' is whether the sanctions are custodial or non-custodial; see European Commission (n 30) [28(c)]; and L O Blanco (ed), EC Competition Procedure (2nd edn, OUP 2006) [3.30].

39 European Commission (n 30) [28(c)]. 
rights protections may be stronger in one country (due to its national law) than in another, even if both adhere to the ECHR requirements. Assume that both requested and requesting state have criminal antitrust sanctions. If the requested state goes no further than the requirements of art $6 \mathrm{ECHR}$ in its protection of the rights of the accused, then, under reg $1 / 2003$, it is that level of protection that is achieved. However, if the requested state has a level of protection that is more robust than that required by art $6 \mathrm{ECHR}$, the higher level of protection is operative. When both jurisdictions impose criminal sanctions, it is the human rights protections of the requested state that matter: it is irrelevant that the requesting state has in place higher levels of protection than the requested state. Due to the operation of art 12(3), then, at the very least (and assuming that the member states respect their ECHR obligations) art 6 ECHR will be respected when both jurisdictions impose criminal sanctions on natural persons; but more robust protections may also be secured, depending upon the (national) human rights law of the requested state.

A relatively similar situation is reached where only the requesting state has criminalised its regime: when the transmitting country does not have criminal sanctions and therefore has not necessarily gathered evidence according to criminal standards, such information can only be used as intelligence, not evidence, unless the human rights protections of the receiving country have been respected. It is assumed here that the human rights guarantees of the receiving country will at the very least respect art 6 ECHR. Again, the actual level of protection secured may be higher, and all depends upon the relevant national law. But this time, of course, the relevant national law is that of the requesting state, not the requested state. There is, however, an extra protection if the requested state does not employ criminal sanctions: if information is used in evidence in the requesting state, only non-custodial punishment may be imposed. These stricter rules are ostensibly designed to preserve the higher level of protection that individuals usually benefit from in comparison to undertakings. 40

\section{Critically evaluating art 12(3)}

One could argue that, as a direct result of art 12(3), the due process rights of the accused are adequately protected while: (a) no obstacles are placed in the way of information exchange between criminal antitrust jurisdictions; and (b) no unreasonable obstacles are placed in the way of information exchange between administrative and criminal antitrust jurisdictions. For this to be so, one must first accept the logic of the assumption that art 6 ECHR (or its equivalent) will be protected in the member states. This is not difficult to do. First, the ECHR, as an international treaty, is binding on all the EU member states ${ }^{41}$ and, although infringements of art 6 ECHR may occasionally occur in practice, the member states must nonetheless acknowledge and respect the mandatory nature of rulings addressed to them by the European Court of Human Rights (ECtHR). ${ }^{42}$ Member states, then, are restrained in their activities by the ECHR. ${ }^{43}$ Second, fundamental rights are respected as general principles of EU law, and when member states apply EU law they are under the obligation to comply with EU requirements concerning the protection of fundamental rights. Such human rights protections find their inspiration in, inter alia, the ECHR, including art 6 thereof. ${ }^{44}$ Consequently, the assumption appears to be sound. If so,

40 A Türk, 'Modernisation of EC Antitrust Enforcement' in H Hofmann and A Türk (eds), EU Administrative Governance (Edward Elgar Publishing 2006) 223.

41 D Gomien, Short Guide to the European Convention on Human Rights (Council of Europe 2005) 12.

42 See eg art 46(1) ECHR.

43 But this is not to say that the signatories must give direct effect to the ECHR within national law: Ireland $v$ UK (1978) 2 EHRR 25. In fact, there is 'wide variation' in the extent to which the signatories have done so: M Janis, R Kay and A Bradley, European Human Rights Law: Text and Materials (3rd edn, OUP 2008) 850.

44 See art 6(3) TEU. 
the exchange of information between two criminal antitrust jurisdictions is not problematic under European human rights law.

The case where information is exchanged between an administrative and a criminal regime is less straightforward, however. Again, the assumption that art 6 ECHR will be protected in the member states is made; and again that assumption appears to be sound. Hence, the human rights of the accused are protected (at least) to the ECHR standard. However, an extra obstacle exists concerning the use in evidence of the information, even where the art 6 ECHR rights of the accused have been protected: custodial sanctions cannot be imposed. It is not evident why such a rule (the 'custodial rule') is necessary. If the human rights protections of the requesting state are met then, putting aside the issue of proof concerning such protection, there should be no real issue concerning an imbalance of the requirements of due process between the administrative regime which gathered the information and the criminal one which receives it and uses it in evidence.

Perhaps human rights concerns are not at issue here and in fact politics dominates: some member states may have been concerned about the use of criminal sanctions per se to enforce EU competition law and may not have wished to see information collected in their respective jurisdictions being used to imprison executives in other member states. The existence of the custodial rule arguably illustrates that 'custodial sanctions for violations of competition law are not a matter of consensus within the Union at present'. ${ }^{5}$ Working documents from the Council of Ministers support this view. ${ }^{46}$ Nonetheless, although one can interpret art 12(3) as reflecting 'hostility' towards custodial sanctions, ${ }^{47}$ such hostility is less openly reflected in reg 1/2003 than in the original Commission proposal for a new implementing regulation, where it was proposed 'to exclude the use of evidence exchanged for imposing penalties other than pecuniary penalties'. 48 Provided that the assumption about art 6 ECHR is sound, there is no reason founded in European human rights law for such a strict approach to the issue of information exchange. If reg $1 / 2003$ is to be reformed, ${ }^{49}$ then the (unnecessary) custodial rule should be abolished in the process: to the extent that the threat of imprisonment is more effective in ensuring deterrence than administrative/criminal fines, ${ }^{50}$ such a rule reduces in practice the deterrent effect of (criminal) antitrust sanctions, without any justification based upon legality or practicality. The Commission itself has acknowledged that discussions have arisen concerning whether the custodial rule is 'is too far-reaching and is an obstacle to efficient enforcement'. ${ }^{51}$ Consequently, it 'may be appropriate to examine whether other options are available, while fully preserving parties' rights of defence'. ${ }^{2}$ One possible solution is the abolition of the custodial rule and the use of a 'double barrier' which allows for the information exchanged to be used in evidence to secure custodial sentences provided that: (a) the transmitting

45 C Gauer, 'Due Process in the Face of Divergent National Procedures and Sanctions' (Conference Paper, Antitrust Reform in Europe: A Year in Practice Papers, Brussels, 9-11 March 2005) 51.

46 See eg Document 11791/02 of 4 September 2002, which was produced by the Competition Working Party to the Permanent Representatives Committee: <http://register.consilium.eu.int> accessed 12 June 2013.

47 Perrin (n 7) 547.

48 European Commission, Proposal for a Council Regulation on the Implementation of the Rules on Competition laid down in Articles 81 and 82 of the Treaty and Amending Regulations (EEC) No 1017/68, (EEC) No 2988/74, (EEC) No 4056/86 and (EEC) No 3975/87 (COM(2000) 582 final, Brussels, 27 September 2000) 21. See also ibid 41.

49 On this, see <http://ec.europa.eu/competition/consultations/2008_regulation_1_2003/index.html> accessed 12 June 2013.

50 See Wils (n 11); and Whelan (n 23).

51 European Commission, Communication from the Commission to the European Parliament and the Council: Report on the Functioning of Regulation 1/2003 (COM(2009) 206 final, Brussels, 29 April 2009) [32].

52 European Commission (n 51) [32]. 
authority verifies that the information transmitted conforms with its rules on admissibility; and (ii) the receiving authority verifies that the information received can be used in conformity with its rules. ${ }^{53}$ Such an approach would resolve the due process-related problem noted above, while minimising the negative impact upon the efficiency and effectiveness of European antitrust enforcement.

Interestingly, it has been argued that the mere coexistence of criminal and administrative sanctions inevitably places a major obstacle in the way of information exchange within the ECN. For Perrin, art 12(3) of reg $1 / 2003$ results in 'a considerable fracture in the supposedly unified EU Network into two distinct networks whose fault line is based on the decision of member states to impose custodial [antitrust] sanctions'. ${ }^{54}$ Accordingly, EU jurisdictions imposing custodial sanctions for antitrust offences 'will find themselves excluded from the larger EU Network and demoted to the smaller EU Network of likeminded member states'. ${ }^{5}$ The author respectfully disagrees with this argument, for two reasons. First, the art 12(3) prohibition on the use of exchanged information to secure custodial sanctions in the receiving state only extends to the use by the receiving member state of such information in evidence. Member states may legally send information to other member states (which impose custodial sanctions) to facilitate the latter in their investigation of alleged cartel activity. Furthermore, the receiving member states (who impose custodial sanctions) are legally entitled to use such information to detect and to obtain proof of rather than to use as evidence of - a violation of art 101(1) TFEU. Second, there is no formal/informal punishment mechanism which can be used against those member states without criminal antitrust sanctions who transfer information to member states with criminal sanctions where the latter then use that information in evidence to secure custodial sentences. In short, there is no negative 'fallout' for the sending member state. All that art 12(3) of reg 1/2003 does is ensure that the receiving member state will be restrained in its employment of the information: it does not ensure that such information will not be exchanged in the first place. If information is used in a manner which is inconsistent with art $12(3)$ of reg $1 / 2003$, it is only the receiving member state that will be at fault. Consequently, it is not exactly clear why the mere exchange of information through the ECN will result in a two-tier entity.

Admittedly, the coexistence of criminal and administrative sanctions is not without its problems, even with art $12(3)$ of reg $1 / 2003$. One particular difficulty comes to mind: determining whether the collection of information respects 'the same level of protection of the rights of defence of natural persons as provided for under the national rules of the receiving authority'. ${ }^{5}$ This inquiry is relevant when a member state that imposes administrative sanctions sends information to another member state which is then used in evidence to secure a criminal cartel conviction. In such a situation, the defendant could claim that such information should not be used in evidence against her as its collection did not respect the same level of rights protection provided to natural persons in the receiving state. Indeed, for Perrin, the use of information in such a context would 'be highly vulnerable to frequent challenges on the part of defendants who are natural persons'. ${ }^{57}$ This is a strong argument: criminal sanctions can be severe; and defendants will likely present

53 See European Commission, Commission Staff Working Paper Accompanying the Communication from the Commission to the European Parliament and the Council: Report on the Functioning of Regulation 1/2003 (SEC(2009) 574 final, Brussels, 29 April 2009) [245].

54 Perrin (n 7) 555.

55 Ibid.

$56 \operatorname{Reg} 1 / 2003$, art 12(3).

57 Perrin (n 7) 555. 
whatever (reasonable) claim they can to avoid conviction. Nonetheless, irrespective of whether such claims by the defendant would be as frequent as contended by Perrin, it is true that, to rule on such a claim, the relevant national judge(s) would need to evaluate the protections secured in the sending state, an exercise that might be burdened by language difficulties and/or a lack of cooperation from the sending NCA. Reliable information on the procedural guarantees of other member states thus increases in importance due to European antitrust criminalisation. Obtaining such information in any given case increases the costs associated with enforcement. Challenges by defendants on this ground alone therefore have potential to affect the cost-benefit analyses that need to be undertaken by the authorities when deciding whether to introduce criminal antitrust sanctions for the purpose of deterrence: such (likely) challenges impact upon the efficiency of criminal antitrust enforcement.

\section{(B) NE BIS IN IDEM}

The principle of ne bis in idem, contained in art 4(1) of Protocol No 7 to the ECHR, 58 prevents an individual from being tried or punished more than once for the same offence in criminal proceedings under the jurisdiction of the same state. The principle only relates to a right not be tried or punished twice in 'criminal proceedings'. ${ }^{9}$ However, under the ECHR the term 'criminal' is given an autonomous meaning ${ }^{60}$ and, following the reasoning in Menarini, 61 the term would cover (administrative) competition proceedings, such as those conducted at EU level by the Commission. This fact alone ensures that the principle remains relevant to the additional dynamic contention.

\section{(i) The general operation of the principle}

The guarantee enshrined in art 4 prohibits "trial and punishment "again" for an offence for which the applicant has already been finally acquitted or convicted'.62 Unfortunately, conflicting judgments on the test to be employed in this context exist. ${ }^{63}$ In attempting to 'harmonise' these disparate views, the ECtHR recently placed unity of facts at the centre of the inquiry, holding that art 4 'must be understood as prohibiting the prosecution or trial of a second "offence" in so far as it arises from identical facts or facts which are substantially the same'. ${ }^{64}$ Consequently, the inquiry should focus on those facts which 'constitute a set of concrete factual circumstances involving the same defendant and inextricably linked together in time and space', the existence of which must be proved to secure a conviction or institute criminal proceedings. ${ }^{65}$ Double prosecution as well as double punishment is prohibited; therefore one cannot respect the principle by simply reducing the amount of the second punishment by that of the first. 66

58 Protocol No 7 to the Convention for the Protection of Human Rights and Fundamental Freedoms, as amended by Protocol No 11 (Strasbourg 22 November 1984). Only four member states of the Council of Europe (including the UK and Germany) have not ratified this protocol.

59 On this see Protocol No 7 to the Convention for the Protection of Human Rights and Fundamental Freedoms: Explanatory Report, <http://conventions.coe.int/Treaty/en/Reports/Html/117.htm> [32] accessed 12 June 2013.

60 See Sergey Zolotukbin v Russia, Application No 14939/03 (ECtHR, 10 February 2009) [52].

61 A Menarini Diagnostics SRL v Italy, Application No 43509/08 (ECtHR, 27 September 2011).

62 Franz Fischer v Austria, Application No 37950/97 (ECtHR, 29 May 2001) [25].

63 Gradinger v Austria, Series A No 328 C (ECtHR, 23 October 1995) [55]; Oliveira v Switzerland, Reports 1998 V (ECtHR, 30 July 1998) [25]-[29]; and Franz Fischer v Austria, Application No 37950/97 (ECtHR, 29 May 2001) [25].

64 Sergey Zolotukbin v Russia, Application No 14939/03 (ECtHR, 10 February 2009) [82].

65 Sergey Zolotukhin v Russia, Application No 14939/03 (ECtHR, 10 February 2009) [84].

66 Franz. Fischer v Austria, Application No 37950/97 (ECtHR, 29 May 2001) [30]. 
The scope of the principle of ne bis in idem, as enshrined in art 4 of Protocol No 7, remains relatively restricted: the principle only applies to 'acts within the same jurisdiction and does not prevent a person from being convicted for the same offence in a different jurisdiction'. ${ }^{67}$ Parallel antitrust prosecutions by the Commission and an NCA, or by the NCAs of several member states, would therefore fall outside the scope of this provision. Article 4 is therefore only relevant to the first of the manifestations of the additional dynamic contention. Admittedly, however, provided that they are implementing EU law, such parallel prosecutions would not fall outside the scope of ne bis in idem articulated in the EU Charter of Fundamental Rights (CFR). ${ }^{68}$ Article 50 CFR therefore extends the relevance of ne bis in idem to all three of the valid manifestations of the additional 'dynamic' contention.

\section{(ii) European antitrust criminalisation and the relevance of ne bis in idem}

$\mathrm{Ne}$ bis in idem becomes relevant when administrative antitrust sanctions exist alongside criminal sanctions as a broad interpretation has been given to the concept of 'undertaking'. An undertaking is defined as 'every entity engaged in an economic activity, regardless of the legal status of the entity and the way in which it is financed'. ${ }^{69}$ The concept includes entities such as trade associations, agricultural cooperatives, sporting bodies, companies and partnerships. Individuals can be undertakings if they carry out an economic activity. ${ }^{70}$ There are two exceptions to this however: employees ${ }^{71}$ and final purchasers. ${ }^{72}$ If an infringement of art 101 TFEU is found, fines are imposed upon 'persons'; this is due to art 299 TFEU: '[d] ecisions of the Council or of the Commission which impose a pecuniary obligation on persons other than States shall be enforceable'. ${ }^{73}$ Although an undertaking is not always equivalent to a company with legal personality, 'it is necessary for the purposes of applying and enforcing decisions to identify an entity possessing legal personality to be the addressee of the measure. ${ }^{74}$ Fines are therefore imposed upon those legal persons to whom the conduct of the undertaking can be imputed. Because art 299 TFEU only refers to 'persons', fines can presumably be enforced against both 'legal persons' and 'natural persons' (that is, individuals). ${ }^{75}$ So, due to both (a) EU jurisprudence on the concept of an undertaking and (b) art 299 TFEU, 'an individually owned firm and a partnership without a distinct legal personality are undertakings in the sense of EU competition law, and may be fined as such'.76

With cartel criminalisation, for a given (alleged) cartel, a natural person in her capacity as an undertaking may be subject to an administrative fine in addition to a criminal fine that could be imposed upon her solely as a natural person: unity with regard to the identity of the defendant may arise when both (corporate) administrative sanctions and (personal) criminal sanctions are available. This is where the principle of ne bis in idem becomes relevant. For the principle to have effect in practice, two additional elements are required: (i) the existence of (a particular set of) parallel prosecutions; and (ii) the fact that the second

67 Blanco (n 38) [4.44].

68 See art 50 CFR.

69 Höfner and Elser v Macrotron (C-41/90) [1991] ECR I-1979 [21].

70 See eg IV/29.559, RAI/UNITEL [1978] OJ L157/39 (opera singers) (Commission Decision, 15 June 1978); and IV/28.996, Reuter/BASF [1976] OJ L254/40 (individual inventors) (Commission Decision, 26 July 1976).

71 Albany International BV v Stichting Bedrijfspensioenfonds Textielindustrie (C-67/96) [1999] ECR I-5751.

72 FENIN v Commission (T-319/99) [2003] ECR II-357 [36].

73 Emphasis added.

74 Limburgse Vinyl Maatschappij and Others v Commission (T-305-307/94 etc) [1999] ECR II-945, [978].

75 See W Wils, Optimal Enforcement of EC Antitrust Law: A Study in Law and Economics (Kluwer Law International 2002) 176.

76 Zuleeg (n 8). 
prosecution concerns an offence for which an individual has already been finally acquitted or convicted in the first prosecution (which is termed here 'equivalence of offence').

The existence of parallel prosecutions is the least problematic element. According to art 4(1) of Protocol No 7, the principle may only be relevant when the administrative fine is imposed by the same jurisdiction as that imposing the criminal sanction. However, with art 50 CFR, the principle is extended to include antitrust proceedings in other member states. When applicable, art $50 \mathrm{CFR}$ captures two further scenarios: parallel antitrust prosecutions by the Commission and an NCA, and parallel antitrust prosecutions by the NCAs of two or more member states. All three of the valid manifestations are therefore relevant here. The principle will not be infringed where there are parallel antitrust prosecutions involving a member state and a non-EU jurisdiction.

The second element, equivalence of offence, is more complex. Recent jurisprudence requires a factual analysis to be undertaken in situations where the issue of ne bis in idem may arise. One must determine the facts required to secure a conviction or institute criminal proceedings in relation to both the administrative and the criminal antitrust offence. If these facts are identical or substantially similar then ne bis in idem will apply. Where the (national) criminal antitrust offence merely provides criminal sanctions for violation of art 101 TFEU, there is no real problem: the only difference between the administrative and the criminal proceedings will be the nature of the sanction imposed and not the underlying conduct which is punished; and if the underlying conduct is the same, the facts which are required to convict will also be equivalent. A different outcome may occur, however, when antitrust criminalisation involves the creation of a separate stand-alone criminal offence with elements additional to those included within art 101 TFEU. ${ }^{77}$ The test for equivalence of offence no longer focuses on the essential (definitional) elements of the offences; therefore, the existence of such additional elements does not ipso facto ensure the irrelevance of ne bis in idem concerns. If, however, the additional elements ensure that a different set of concrete factual circumstances surrounding the cartel are relevant to the criminal antitrust offence from those relevant to the administrative offence, there would be no potential ne bis in idem problem. This is a factual inquiry. To determine if the principle is operative, one must: (a) study the facts relied upon in the previous decision (or judgment); (b) examine the facts as stated in the relevant indictment (or the Statement of Objections); and (c) decide whether the facts in (a) and (b) are identical or substantially the same. Where they are not, there is no issue with ne bis in idem. When (substantial) factual identity exists, the principle will apply.

\section{(iii) Dealing with ne bis in idem in the context of European antitrust criminalisation}

The easiest case to deal with occurs where the second antitrust prosecution has begun or is about to begin. In this scenario, when the principle is operative, the charge against the individual (or, alternatively, the undertaking represented by an individual) should be dropped. The reason for this is clear: double prosecution is prohibited by art 4(1), and one cannot stay within the principle simply by reducing the amount of the second sanction by that of the first. The situation becomes more complicated when neither of the two parallel prosecutions has begun and a decision is required concerning whether to proceed with a prosecution and, if so, which one, administrative or criminal. (In such a situation, it may also be difficult to establish whether a ne bis in idem problem is likely: in practice, one will be precluded from following the three-step methodology noted above, and one may therefore have difficulty in determining the existence of factual identity.) If the prospective criminal and administrative prosecutions will occur in the same member state, then it will be the authorities of that member state which will have to weigh up the relative merits and

77 An example is the UK Cartel Offence: s 188 of the Enterprise Act 2002. 
demerits of the prospective prosecutions. They should consider resource constraints, likelihood of success, impact upon compliance and, importantly, the degree to which the objectives of the law will be achieved.

When another member state or the Commission is involved (that is, when art 50 CFR becomes relevant), it will be necessary for the authorities to communicate with one another and to resolve the issue through dialogue. Identifying and neutralising any potential ne bis in $i d e m$ problem at the outset is advisable: it avoids the waste of time and resources engendered when cases later collapse on human rights grounds. The ECN may be useful here. Under reg $1 / 2003$, the NCAs, when acting under art 101 TFEU, are obliged to inform the Commission (a) after commencing the first formal investigative measure ${ }^{78}$ and (b) no later than 30 days before taking a decision. ${ }^{79}$ The other member states' NCAs 'may' also be so informed. ${ }^{80}$ Such a flow of information is helpful as it notifies the competition authorities of possible parallel investigations/prosecutions, thereby enabling them to allocate cases amongst themselves to eliminate potential ne bis in idem problems. Nonetheless, there are difficulties with the employment of the ECN as a preventive mechanism.

The first difficulty is that there is no obligation concerning inter-NCA notifications. The second is that, due to the vagueness of recital 8 of reg 1/2003, NCAs may not feel obliged to inform the Commission of criminal antitrust cases which involve the imposition of sanctions upon natural persons. Both deficiencies have potential to undermine the ability of the ECN to operate as a preventative mechanism: the authorities of the relevant jurisdictions may not be aware of the potential parallel investigation and prosecution and, hence, the need to discuss appropriate case allocation. Consider the following example. NCA 1 informs the Commission of its (administrative) investigation of undertaking X (an individual); NCA 1 does not inform any other NCA about the investigation; NCA 2 does not inform the Commission (or any NCA) about its prospective criminal case against the individual that constitutes undertaking X. In this scenario, the ne bis in idem problem will only become apparent (if detected) once the second prosecution begins; in other words, the ECN would not have been able to operate effectively and eliminate the ne bis in idem concern before it developed. Finally, the NCAs cannot relieve each other of the competence to pursue a given antitrust investigation or prosecution. Any resolution of the issue will therefore require the consent of all relevant NCAs. ${ }^{81}$ The Commission itself may use art 11(6) of reg 1/2003 to investigate the (individual comprising the) undertaking itself, thereby relieving an NCA of its competence to apply art 101 TFEU. While this power may appear useful in preventing the emergence of ne bis in idem problems, it too suffers from limitations. Importantly, art 11(6) is likely only to be used in very exceptional circumstances and only where the EU interest so dictates: it is not a panacea when conflict between NCAs develops. ${ }^{82}$ Furthermore, art 11(6) only relieves the NCAs of their competence to apply art 101 TFEU; it does not relieve criminal courts of their power to impose sanctions for violation of the criminal law when such courts are not NCAs for the purpose of reg $1 / 2003$. Moreover, if a national cartel offence is not actually a 'national competition law' for the purposes of reg $1 / 2003,83$ then art 11(6) will not have any impact on the national criminal proceeding as reg $1 / 2003$ will not apply. It is not inconceivable, then, that potential

$78 \operatorname{Reg} 1 / 2003$, art 11(3).

79 Ibid art 11(4).

80 Ibid arts 11(3) and 11(4).

81 On the ability of the NCAs to terminate their own antitrust proceedings when there is a parallel (art 101 TFEU) proceeding in another member state, see reg 1/2003, art 13.

82 See generally European Commission (n 30) s 3.2.

83 On this, see IB $v$ The Queen [2009] EWCA Crim 2575. 
ne bis in idem problems will not be neutralised before the commencement of the parallel prosecutions. This effectively returns one to the first situation examined above: if parallel antitrust prosecutions are not prevented by the competition authorities, then the charges in the second prosecution should be dropped to respect due process.

\section{(iv) Consequences of respecting the principle of ne bis in idem}

If cartel activity is criminalised for retributive reasons, one would have to establish measures to ensure that a cartelist is protected from excessive punishment for her wrongful conduct: the theory of retribution ensures that a person shall be subjected to no more punishment than she deserves. One such measure could be a judicially recognised prohibition on an individual being tried/punished more than once for the same wrongful conduct. The principle of ne bis in idem can therefore be rationalised in part using retribution theory. As noted above, however, the principle can require one to drop the second antitrust prosecution to respect due process. This fact influences the effectiveness of an enforcement policy premised on the achievement of deterrence. The reason for this is as follows. If the enforcement action represented by the first prosecution is indeed an administrative proceeding, it will be the criminal proceeding that will have to be dropped. The administrative proceeding, then, will be the only proceeding against the individual cartelist (who is also an undertaking). Significant deficiencies concerning the use of administrative antitrust sanctions alone to secure deterrence exist, including both the inability of the competition authority to impose an optimal fine and the inability of the undertaking to pay such a fine. ${ }^{84}$ As, under the circumstances identified, only an administrative proceeding is legally possible, these deficiencies would continue to be relevant. Consequently, sub-optimal deterrence may result when, due to ne bis in idem, only an administrative sanction is imposed for a given cartel.

\section{(c) Concurrent PRoceEdings}

All three of the valid manifestations of the additional dynamic contention are relevant to concurrent proceedings: they all concern two separate antitrust proceedings which take place either simultaneously or within a short period of time of each other. Such concurrent proceedings raise two due process-related issues.

\section{(i) Two due process-related issues}

The first due process-related issue arises because the substance of due process rights (at least under the ECHR) is not exactly equivalent as regards both criminal and administrative regimes. ${ }^{85}$ Assume that an antitrust authority is conducting an administrative investigation against an undertaking using its administrative powers. During that administrative proceeding, the antitrust authority uncovers evidence implicating a particular individual cartelist. The antitrust authority then decides to commence a criminal proceeding against that individual. If the due process rights protected under the administrative proceeding are not as robust as those to be respected under a criminal proceeding, the evidence collected using the administrative powers could not be used in a criminal court without violating art 6 ECHR. Of course, if evidence is collected to a criminal standard and is then used in an administrative proceeding, there should be no human rights-based objection: the strictest of legal guarantees will have been observed and potential prejudice will be absent. ${ }^{86}$

84 See Whelan (n 23).

85 On these differences, see Whelan (n 6).

86 See eg HL Deb 29 July 2002, vol 638, col 73 (Lord Sailsbury). 
The second due process-related issue concerns the creation of prejudicial pre-trial publicity. Such publicity may be created if an administrative cartel proceeding precedes any related criminal proceedings against an individual. The reason for this should be clear: if a (public) administrative decision determines that a market has been cartelised, it may be publicised by the international media, particularly if the market is important for consumers. The media could be critical of not only the undertakings involved, but also of their staff. Consequently, such negative publicity may influence potential jurors in a later criminal trial involving an individual employee of that undertaking. Such publicity could engender impartiality in the court to the detriment of compliance with art 6 ECHR. ${ }^{87}$

\section{(ii) Ensuring consistency with due process}

To avoid the first due process-related issue, one should not present evidence in a criminal court if it is gathered only to the administrative standard, otherwise one will likely violate art 6 ECHR. Criminal antitrust proceedings should respect the rights of the accused to a criminal standard at all stages of the investigation and prosecution. This is not to say, however, that parallel (criminal and administrative) investigations by the same public antitrust body in a given member state cannot be conducted. ${ }^{88}$ In fact, such parallel enforcement actions can be successfully conducted if mechanisms exist to avoid the relevant due process-related issue.

The first required mechanism is a system which ensures from the outset that the administrative investigative team is functionally and materially separate from the criminal investigative team. Under this system, each investigative team acquires evidence according to its powers and respects the appropriate level of due process rights (administrative or criminal). What is to be avoided here is the 'fusion' of the investigations (ie, the treatment of the administrative and criminal investigations as one single investigation), not their parallel advancement (by separate teams within the antitrust enforcement agency). ${ }^{89}$

A second mechanism should exist to ensure that this division of enforcement teams remains solid throughout both investigations. If different teams within the one authority are pursuing respectively administrative and criminal investigations, 'Chinese walls' must be established between these teams. ${ }^{90}$ In particular, if information or evidence is to move from one investigative team to another, then it should first pass through a screening process involving lawyers who are not part of either investigative team. These lawyers should be qualified to appreciate whether, in passing on the relevant information or evidence and allowing it to be used by others, due process will be undermined. Where this is likely, the information or evidence in question should not be passed on. Legislation (and/or soft law) $)^{91}$ could also be adopted to provide clarity to antitrust enforcers on legitimate information exchange. Such legislation could detail, for example, the circumstances in which information passed from the administrative team to the criminal team can be legitimately relied upon in court. ${ }^{92}$

87 For ECtHR jurisprudence on impartiality contrary to art 6 ECHR, see eg De Cubber v Belgium (1984) 7 EHRR 236 [24]; Gregory v UK (1997) 25 EHRR 577 [45]; and Hauschildt v Denmark (1989) 12 EHRR 266 [46].

88 See Nazzini (n 9).

89 Ibid 485.

90 M Frese, 'The Negative Interplay Between National Custodial Sanctions and Leniency' in K Cseres, P M Schinkel and F Vogelaar (eds), Criminalization of Competition Law Enforcement: Economic and Legal Implications for the EU Member States (Edward Elgar Publishing 2006) 206. On the (successful) use of Chinese walls in the UK criminal cartel regime, see E Morgan, 'Criminal Cartel Sanctions under the UK Enterprise Act: An Assessment' (2010) 17(1) International Journal of the Economics of Business 67, 72.

91 See eg OFT, Powers for Investigating Criminal Cartels (OFT 515, January 2004) [4].

92 See eg Competition Act 1998 (CA), s 30A 
Finally, to ensure efficiency in enforcement, a formalised decision-making process should be initiated which will determine whether an administrative or criminal proceeding (or both) should be followed for a given cartel. If it is unclear initially which type of proceeding should be initiated, evidence should be collected to the criminal standard. Such an approach exists in the UK: the Office of Fair Trading (OFT), when pursuing cartel cases, often ensures that criminal standards are followed, even in the course of an administrative proceeding. ${ }^{93}$ It is only when it becomes clear that an administrative proceeding should also be initiated (or should take the place of the criminal investigation) that the administrative standards should be deemed relevant. By creating a formal structure (composed of experienced investigators and/or prosecutors) which determines whether an investigation should be criminal or administrative (or both), one can ensure that due process is not violated, while limiting the amount of resources spent on unnecessary investigative efforts. It can also help to avoid situations where evidence is initially collected using administrative powers but which then must be reacquired using criminal powers.

To avoid the second due process-related issue, one could ensure that the outcome of the criminal proceeding is resolved before that in the administrative proceeding: negative publicity is less likely to affect a criminal trial in the absence of a prior formal public decision concerning the actual existence of the cartel in question. ${ }^{94}$ Admittedly, such an approach may not always be possible. For example, the administrative proceeding may take place in a different jurisdiction than the criminal proceeding. ${ }^{95}$ In such a situation, it would be open to the criminal jurisdiction to request that the administrative proceeding in the other jurisdiction be stayed pending the outcome of the criminal trial; but such a request would not have to be granted by the other jurisdiction (or may not be possible under its law).

But this may not necessarily be a problem. As (negative) publicity surrounding cartel decisions is often of limited duration and of limited interest to the public, one cannot assume that it automatically becomes prejudicial to a criminal trial. Second, the antitrust authority could simply de-emphasise the importance of the administrative proceeding (for instance, by not commenting on it publicly) in an attempt to limit the interest of the national media. This option is particularly relevant when only the first manifestation of the additional dynamic contention is operative: the antitrust authority will have more influence over the extent of publicity surrounding the administrative antitrust decision than it would have if it was adopted by a foreign authority (which presumably would have a strong interest in publicising its enforcement results). Third, to reduce the negative potential of publicity, one could delay the criminal cartel trial for a short period of time to allow a 'fade effect' to develop. ${ }^{96}$ 'Too long of a delay may, of course, engender problems. For example, the memories of witnesses may also begin to fade with time. Finally, even if one could establish that publicity may influence decision makers in the criminal cartel trial, it would still be difficult to establish a legal challenge to that trial alleging a violation of art 6 ECHR. The reason for this is that under ECtHR jurisprudence, the existence of negative publicity per se is not decisive concerning impartiality; one should also consider the effectiveness of measures offered to exclude any legitimate doubt concerning prejudice. ${ }^{97}$ As noted by Lord Hope:

93 See OFT (n 91) [4.1] and [4.9]; and OFT, The Proposed Criminalisation of Cartels in the UK: A Report Prepared for the Office of Fair Trading by Sir Anthony Hammond KCB QC and Roy Penrose OBE QPM (OFT 365, November 2001) [1.20].

94 See OFT, Proposed Criminalisation (n 93) [1.20].

95 Ibid.

96 See Nazzini (n 9) 486.

97 De Cubber v Belgium (1984) 7 EHRR 236 [24]. See also Pullar v UK (1996) 22 EHRR 391 [40]. 
the question is not confined to the residual effect of the publicity on the minds of each of the jurors. Account must also be taken of the part which the judge will play to ensure, so far as possible, that the defendants will receive a fair trial. An examination of the measures which [she] can take under the system which has been laid down for the conduct of criminal jury trials forms an integral part of the whole exercise. ${ }^{98}$

The relevant measures include, in particular, warnings or directions provided to the jury by the trial judge. ${ }^{99}$ For an argument concerning prejudicial pre-trial publicity to be successful in a criminal cartel case, then, one must convince a court that the available judicial measures are ineffective in protecting against impartiality. This may be difficult to do in practice, even if academic literature supports the argument: ${ }^{100}$ the effectiveness of judicial directions may represent a 'convenient fiction'101 which the judiciary is generally content to accept.

\section{(iii) Impact upon the objectives of criminalisation}

The main reason that the techniques identified are capable of affecting deterrence is that to implement these techniques one must expend resources. Additional resources are inevitably consumed when: (a) evidence collected to an administrative standard is then recollected to a criminal standard; (b) the investigation respects a (more demanding) criminal standard from the outset instead of an administrative standard (even when, ultimately, an administrative sanction results); and (c) mechanisms, such as Chinese walls, are formalised, as staff independent of the investigative teams are required. Such increases in costs are relevant to economic deterrence as such an objective seeks to achieve economic efficiency. These additional costs need to be fed into the cost-benefit analysis conducted when deciding whether to introduce criminal antitrust sanctions and further complicate the decision whether to criminalise. The real question that arises is whether the additional costs concerning the techniques can be offset by the increase in benefits (due to marginal deterrence) secured by the criminalisation. This is a factual issue. The point here is that the protection of due process does in fact influence that particular analysis; hence such protection affects the objective of deterrence.

The techniques which may impact upon the achievement of retribution are those related to the protection against prejudicial pre-trial publicity. When pursuing the objective of deterrence alone, one does not necessarily have to protect against negative publicity: (general) deterrence theory per se does not require that only the guilty are punished, unless such (undeserved) punishment is capable of undermining the general level of respect for the criminal law and therefore its deterrent effect. In fact, if citizens genuinely believe that an individual is guilty of a criminal cartel offence, her conviction (even if erroneous) may increase their respect for the law and may increase general deterrence. With retribution, by contrast, such an approach is prohibited: only deserved punishment can be imposed; negative pre-trial publicity which leads to an erroneous conviction is inconsistent with this objective. To the extent, then, that the identified techniques concerning the avoidance of prejudicial pre-trial publicity are effective, such techniques can ensure consistency with retribution.

98 Montgomery v HM Advocate [2003] 1 AC 641, 670.

99 See T M Honess, 'Empirical and Legal Perspectives on the Impact of Pre-Trial Publicity' [2002] Criminal Law Review 719, 720.

100 See eg P Fitzpatrick, 'The British Jury: An Argument for the Reconstruction of the Little Parliament' [2010] Cambridge Student Law Review 1. See also C Thomas, 'Are Juries Fair?' (Ministry of Justice Research Series 1/10, February 2010) <www.justice.gov.uk/publications/are-juries-fair.htm> accessed 12 June 2013, demonstrating that a high proportion of jurors do not understand judicial directions fully in the legal terms used by judges.

101 J A Tanford, 'The Law and Psychology of Jury Instructions' (1990) 69 Nebraska Law Review 71, 111. 
Nonetheless, one technique could undermine retribution: limiting the interest of the national media in the concurrent administrative antitrust proceeding. This technique is problematic as, given the nature of cartel activity, 'norm-building' will be required during the early stages of criminal enforcement to operationalise the objective of retribution. ${ }^{102}$ In particular, the authorities must create awareness of the moral content of cartel activity. The easiest way to do this is to adopt administrative decisions condemning cartel activity while creating publicity surrounding such decisions. When such publicity is shunned, efforts to create awareness of the moral content of cartel activity will be undermined. This problem can be avoided, however, if the administrative antitrust proceeding follows the criminal one. Accordingly, maximum publicity can be created concerning the administrative proceeding without damaging the sustainability of the criminal conviction. It is only when the administrative antitrust proceeding actually precedes the criminal proceeding that the tension between the objective of retribution and respect for due process is created.

\section{Conclusion}

Due process presents difficult challenges for those considering the introduction of criminal antitrust sanctions within the EU. Some of these challenges are the natural result of the additional dynamic contention, which holds that the introduction of criminal antitrust sanctions in a European jurisdiction does not preclude the additional imposition of administrative sanctions for a given cartel. The validity and impact of the additional dynamic contention were examined to present a more comprehensive understanding of the legal challenge of due process for European antitrust criminalisation.

The validity of the additional dynamic contention was considered first. Three different sentencing scenarios for a given cartel were found to be legally possible and likely in practice. The additional dynamic contention was therefore found to be valid. The next analytical step determined the actual impact of the additional dynamic contention and, hence, the extent of the challenge presented by due process. Three issues were considered: the exchange of information; double jeopardy; and concurrent proceedings.

A potential due process issue was identified with the exchange of information from administrative antitrust regimes to criminal antitrust regimes: if such information could be used in evidence in a criminal trial, it could potentially undermine due process, as the protections in an administrative regime may not be as robust as those in a criminal regime. While EU law has foreseen this problem, its response arguably goes too far: it prohibits the use of information in evidence to secure custodial sanctions in a receiving (criminal) regime even where the sending (administrative) regime has respected the human rights guarantees in the receiving state. To ensure that the objectives of antitrust criminalisation are not undermined, this custodial rule should be abolished. Alternative, less strict protections could also be introduced, such as the use of a double barrier. However, if due process is indeed to be protected, it is necessary to accept an inevitable negative impact upon the efficiency of the criminal antitrust regime: legal appeals questioning whether the relevant collection of information respects the equivalent level of protection of the rights of the accused in the receiving jurisdiction inevitably consume resources. Compensating for this reduction in efficiency represents an inherent legal challenge of European antitrust criminalisation.

The second identified issue of due process concerned double jeopardy. This issue becomes relevant due to: (a) the validity of the additional dynamic contention; and (b) the fact

102 See P Whelan, 'Morality and its Restraining Influence on European Antitrust Criminalisation' (2009) 12 Trinity College Law Review 40. 
that an individual can constitute an undertaking under EU law. One must avoid those rare cases where double jeopardy issues arise when both administrative and criminal sanctions are imposed for a given cartel. The least difficult situation occurs when the second prosecution has not yet begun, but the first prosecution has: the second prosecution should be dropped. When neither prosecution has begun, the situation becomes problematic, particularly where more than one jurisdiction is involved. The ECN can be used to resolve the issue. But three limitations were identified with this solution: (i) there is no obligation concerning inter-NCA notifications within the ECN; (ii) the NCAs may not feel obliged to inform the Commission of antitrust cases involving the imposition of sanctions upon individuals; and (iii) the NCAs cannot relieve each other of the competence to pursue antitrust cases. These limitations, then, also contribute to the inherent legal problem of due process.

The final identified issue of due process involved concurrent proceedings. Two potentially problematic matters were identified: (a) the use of administrative powers to collect evidence for a parallel criminal investigation; and (b) the engendering of prejudicial pre-trial publicity. Techniques can be used to reduce the likelihood of their occurrence. However, efforts to ensure consistency with due process may impact negatively upon the objectives of European antitrust criminalisation. Specifically, such techniques may either increase the costs involved in criminal antitrust enforcement, thereby reducing the possible net (deterrence-based) gain from criminalisation, or require the authorities to limit media interest in the (concurrent) administrative proceeding, to the detriment of retribution. The limitations of the identified techniques further contribute to the inherent legal problem of due process.

The analyses which are presented in this article should help to inform the current debate on European antitrust criminalisation. It is clearly important in the context of this debate that one can establish that neither EU law itself nor the practical challenge of adhering to the dictates of the ECHR precludes in any absolute sense the imposition of criminal cartel sanctions alongside their administrative counterparts for a given cartel. It is significant that procedures can be put in place to minimise the concerns that art $6 \mathrm{ECHR}$ will be violated where one jurisdiction imposes criminal cartel sanctions and another imposes administrative cartel sanctions for a given cartel. This fact ensures that some European jurisdictions can forge ahead with antitrust criminalisation even when a consensus does not exist across Europe concerning the necessity and appropriateness of such criminalisation: it facilitates a slow, measured conversion to antitrust criminalisation for those European jurisdictions which are materially ready for the introduction of criminal cartel sanctions.

It is true too that the option of having both criminal and administrative sanctions on their legislative books is arguably an attractive option for some European jurisdictions with a relatively developed competition law culture. The current literature establishes that robust arguments can in fact be put forward as to why criminal sanctions on individuals are superior to administrative sanctions on undertakings in achieving deterrence of cartel activity. However, there are also good deterrence-focused reasons for reserving the option of imposing administrative sanctions on undertakings in addition to criminal sanctions on individuals for a given cartel: the absence of a sanction on the company would incentivise the company to encourage cartel activity by its employees as such activity would ultimately benefit the undertaking concerned. Consequently, those European jurisdictions which are serious about enforcing their cartel laws may take comfort in the fact that the option of imposing administrative sanctions for a given cartel can still remain a legal possibility even when criminal sanctions have been deployed against individuals involved in that cartel.

None of this is to say, however, that the additional dynamic does not present challenges concerning adherence to art 6 ECHR when enforcing competition law. Indeed, as 
articulated by the analyses presented in this article, the requirement to adhere to art 6 ECHR is capable, in certain circumstances, of impacting upon both objectives of European antitrust criminalisation: deterrence and retribution. By explaining how and when this is so, this article makes a further, novel contribution to the debate on European antitrust criminalisation. Without doubt, those contemplating the introduction of criminal cartel sanctions should be aware of the inherent challenges of adhering to the relevant due process requirements. As noted above, one aspect of due process has been considered in detail in the literature: the claim that the use of criminal cartel sanctions in the place of administrative cartel sanctions inevitably results in a 'strengthening of rights' to the benefit of the accused and to the detriment of the relevant enforcement objectives. However, to understand fully the challenge of due process for European antitrust criminalisation, one must understand whether the imposition of criminal cartel sanctions alongside administrative cartel sanctions for a given cartel presents its own due process challenges. By articulating the specifics of this particular aspect of the challenge of due process, this article allows for a more informed view as to the legal challenges represented by antitrust criminalisation and therefore should help European jurisdictions to come to their own conclusion whether such criminalisation is in fact worth the effort that needs to be expended to make it legally sound in practice. 